\title{
Light and Heavy Chain Components of Gamma Globulins in Urines of Normal Persons and Patients with Agammaglobulinemia *
}

\author{
John H. Vaughan, $\dagger$ Ralph F. Jacox, and Barry A. Gray $\ddagger$ \\ (From the Department of Medicine, University of Rochester School of Medicine and \\ Dentistry, Rochester, N.Y.)
}

\begin{abstract}
Summary. A heavy chain component of $\gamma$ G-globulins in normal urines has the characteristics of the proteolytic digestion product, Fc-fragment. This fragment is estimated to compose up to $15 \%$ of the gamma globulins present in urines. In contrast to urinary light chains, the urinary Fc-like fragment probably represents a catabolic component in normal $\gamma$ G-globulin metabolism.

The light chains of the urine constitute more than half the total gamma globulin present. The calculated $\kappa / \lambda$ ratio of light chains averaged 1.9 in ten urines, but the ratio in individual urines varied widely to either side of this figure.

In two adult patients with agammaglobulinemia whose sera contained less than one-hundredth the normal gamma globulin levels, the urinary Fc-like fragment was absent, whereas the light chain levels were only one-tenth the average normal level. Treatment with exogenous gamma globulins resulted in normal or near normal Fc-like fragment excretion, whereas light chain excretion was only modestly affected.
\end{abstract}

\section{Introduction}

Urinary gamma globulins have been reported to include $7 \mathrm{~S}, 3.5 \mathrm{~S}, 2.0 \mathrm{~S}$, and $1.2 \mathrm{~S}$ components (1-8). Among these components are free light chains as well as what appear to be intact $7 \mathrm{~S} \gamma \mathrm{G}$ globulins. Urinary light chains are derived from the anabolic side of gamma globulin metabolism $(5,9)$. A heavy $(\gamma)$ chain component has also been reported by Freedman and Connell (10) to

* Submitted for publication July 12, 1966; accepted October 27, 1966.

Presented in part at the meeting of the Federated Societies for Experimental Biology, Atlantic City, N. J., April 1965.

Supported by grants AM 08145, AM 02443, FR 44, and $2 \mathrm{~T} 1$ and AI 28 from the National Institutes of Health.

$\dagger$ Recipient, Research Career Award from the National Institutes of Health.

Address requests for reprints to Dr. John H. Vaughan, The University of Rochester School of Medicine and Dentistry, 260 Crittenden Blvd., Rochester, N. Y. 14620.

$\ddagger$ Medical Student Year Out Fellow (1962-1963). Supported by the Dept. of Microbiology and a Medical Student Research Training Grant. be present in urines from normal persons immediately after heavy exercise, and Franklin, Lowenstein, Bigelow, and Meltzer (11) and Osserman and Takatsuki (12) have described abnormal $\gamma$-chains in the urines of patients with " $\mathrm{H}$ chain disease." In Franklin's patient there was evidence to suggest that the $\gamma$-chain component was an anabolic product in gamma globulin metabolism.

This report calls attention to the presence of a $\gamma$-chain component in normal urines obtained from persons engaged in routine daily activities. This component has been shown to be indistinguishable from the $\mathrm{Fc}$-fragment (13) obtained by proteolytic degradation of $\gamma \mathrm{G}$-globulin. From quantitative studies of the excretion of this Fc-like protein after therapeutic injection of $\gamma \mathrm{G}$-globulin into patients with agammaglobulinemia and from studies with leucine- ${ }^{14} \mathrm{C}$ incorporation or with $\gamma \mathrm{G}$ globulin- ${ }^{131} \mathrm{I}$ degradation, we concluded that the urinary Fc-like protein may normally come from $\gamma \mathrm{G}$-globulin catabolism. An estimate is also pro- 
vided of the relative quantities of various gamma globulin components in urine.

\section{Methods}

Urine collections and concentration. Twenty-fourhour urine samples were collected in toluene in a container kept at 4 to $10^{\circ} \mathrm{C}$. Immediately thereafter 10 to $30 \mu \mathrm{g} \mathrm{N}$ of egg albumin was added for each $200 \mathrm{ml}$ of urine as a quantitative marker, and the urines were transferred to dialysis bags, covered with chips of Carbowax, ${ }^{1}$ and allowed to concentrate in the cold about 200 -fold. The concentrated samples were then dialyzed against $0.15 \mathrm{M} \mathrm{NaCl}$ to remove whatever Carbowax had diffused into the dialysis bag. Visking tubing with a 36/32-inch inflated diameter was used throughout. ${ }^{2}$

Immunodiffusion and specific antisera. Estimations of the amounts of specific proteins in the urines were made by a micro-Oudin diffusion procedure (15). Specific rabbit antisera were diluted in normal rabbit serum and mixed at $45^{\circ} \mathrm{C}$ with equal volumes of $0.6 \%$ agar in $\mathrm{pH}$ 7.3 phosphate-buffered saline and $0.01 \%$ merthiolate. Before they hardened, we added the antiserum solutions to 3 - by $60-\mathrm{mm}$ glass tubes, filling them halfway. The tubes were then sealed with small rubber caps and stored

1 Polyethylene glycol compound 20-M from the Union Carbide Chemical Co., New York, N. Y.

2 A number of comparative studies were made with Visking 23/32 tubing, which can be obtained as Nojax 23. This tubing has been shown to be impermeable to light chains in pressure filtration (14), whereas other tubing was permeable. After concentrating by dialysis against Carbowax, however, we found no increased recovery of light chains in urines contained within the $23 / 32$ tubing over that contained within the $36 / 32$ tubing. in batches at $4^{\circ} \mathrm{C}$. The following antisera were used: an antihuman serum albumin (anti-HSA); an anti- $\gamma \mathrm{G}$ globulin containing antibodies to both heavy $(\gamma)$ and light chains; an anti-Bence Jones (anti-BJ) protein of Type $\kappa$; an anti-Bence Jones protein of Type $\lambda$; an anti$\gamma$-chain immunoglobulin prepared by absorbing the anti$\gamma \mathrm{G}$ serum with light chains isolated after reductive cleavage (16) of Fraction II protein; an anti-Fd-fragment ${ }^{3}$ made by absorbing the anti- $\gamma$ serum with $\mathrm{Fc}$-fragment; and antiegg albumin (EA) serum. To assure specificity, the antisera to the gamma globulin components were fully absorbed with appropriate purified gamma globulins and with whole human sera specifically lacking the globulins in question, as previously described (17).

For determinations the tubes were removed from storage and the agar columns overlaid with the concentrated urine specimens or fractions. The tubes were recapped and kept in a constant temperature bath at $20.3 \pm 0.1^{\circ} \mathrm{C}$. The rates of descent of the precipitates in the agar were followed with a cathetometer and compared to those of antigen standards. Straight lines were obtained when the distances of the precipitates from the menisci were plotted against the square root of time, and the slopes of these lines were used to calculate the amounts of the antigens in the urine specimens. The concentration factors for the urines were estimated by comparison of the known amounts of egg albumin added originally to the urines with the amounts present in the concentrated specimens. The concentration factor indicated by the EA values often did not correspond to the volume changes in the urines, giving concentration factors that varied from 65 to $110 \%$ of those indicated by the volume changes. The

3 This serum precipitates in agar with isolated heavy $(\gamma)$ chains and with $\gamma \mathrm{G}$-globulin, but not with Fc-fragment or isolated light chains.

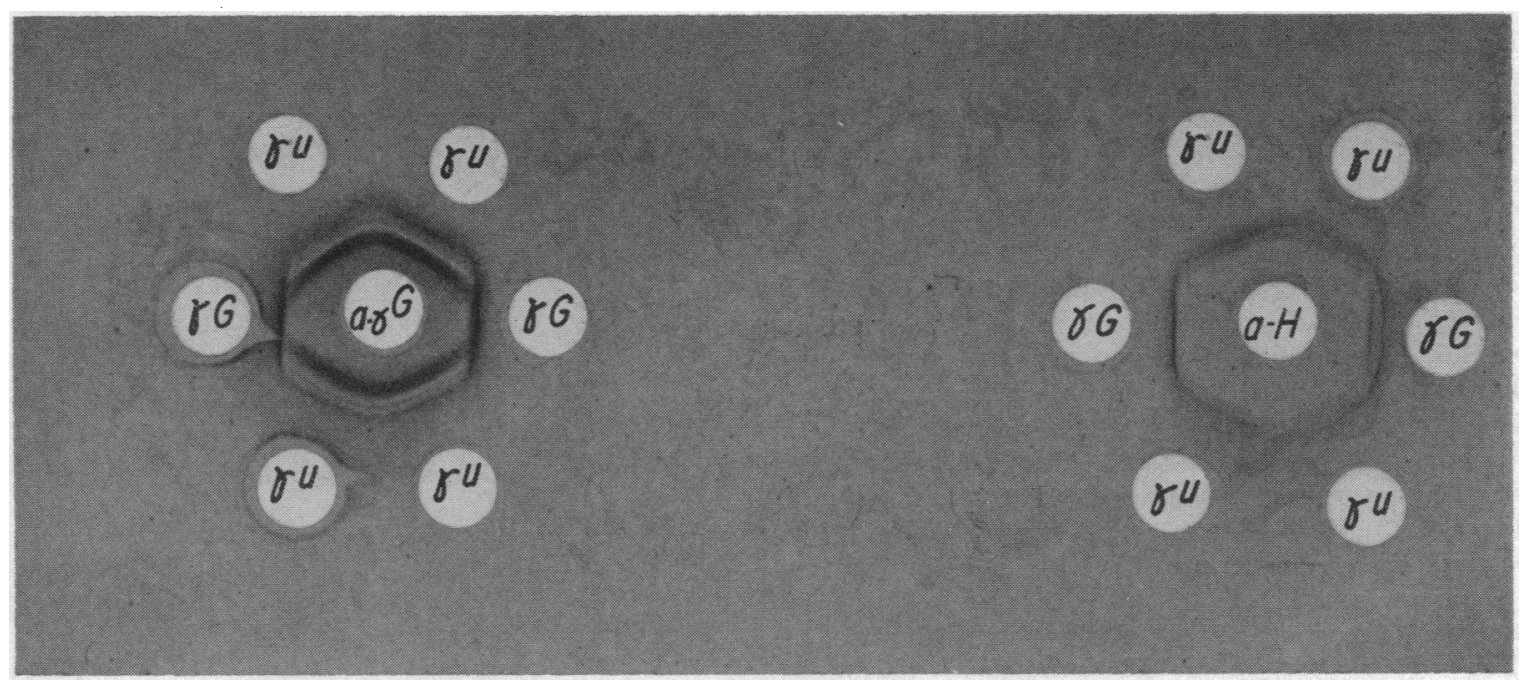

Fig. 1. Left, Reactions in agar of urinary $\gamma$-Globulins $(\gamma \mu)$ and Cohn Fraction II protein ( $\gamma$ G) with Antiserum to Cohn Fraction II $(\mathrm{A}-\gamma \mathrm{G})$. The light chain lines overlap and appear as the heavier broad precipitin line near the center well. Right, Reactions with SAMe antiserum absorbed With Light Chains (A-H). 
TABLE I

Quantities of protein in normal urines

\begin{tabular}{|c|c|c|c|c|c|c|}
\hline & \multirow[b]{2}{*}{ HSA* } & \multirow[b]{2}{*}{$x$-chains } & \multirow[b]{2}{*}{$\lambda$-chains } & \multirow[b]{2}{*}{$\kappa / \lambda$} & \multicolumn{2}{|c|}{ Heavy $(\gamma)$ chain component calculated as } \\
\hline & & & & & Fc-fragment & $\gamma \mathrm{G}$-globulin \\
\hline & \multicolumn{6}{|c|}{$m g N / 24 h r$} \\
\hline B.B. & 4.12 & 0.32 & 0.23 & 1.4 & 0.168 & 2.22 \\
\hline W.M. & 2.44 & 0.25 & 0.14 & 1.8 & 0.270 & 0.98 \\
\hline R.J. & 2.17 & 0.35 & 0.18 & 1.9 & 0.152 & 0.79 \\
\hline F.B. & 1.60 & 0.71 & 0.16 & 4.4 & 0.084 & 0.64 \\
\hline R.C. & 1.44 & 0.29 & 0.44 & 0.66 & 0.079 & 0.58 \\
\hline D.G. & 1.07 & 0.12 & 0.15 & 0.80 & 0.087 & 0.26 \\
\hline J.V. & 0.94 & 0.39 & 0.15 & 2.6 & 0.087 & 0.26 \\
\hline J.L. & 0.87 & 0.81 & 0.28 & 2.9 & 0.084 & 0.65 \\
\hline D.A. & 0.85 & 0.13 & 0.06 & 2.1 & 0.104 & 0.55 \\
\hline J.J. & 0.84 & 0.13 & 0.04 & 3.3 & 0.053 & 0.41 \\
\hline Mean & 1.64 & 0.35 & 0.18 & 1.9 & & \\
\hline Median & 1.25 & 0.31 & 0.16 & 1.9 & & \\
\hline
\end{tabular}

${ }^{*}$ Human serum albumin.

EA data were used in all instances, since losses of protein by adsorption to the dialysis tubing or by leaking of the tubing were assumed to be better accommodated by the EA measurement.

Micro-Ouchterlony analyses (18) were performed on microscope slides in $1 \%$ agar with $\mathrm{pH} 7.0$ phosphatebuffered saline containing $0.5 \mathrm{M}$ glycine and $0.01 \% \mathrm{mer}$ thiolate. The antisera. were the same as used above.

Radioautography. Radiolabeled human $\gamma \mathrm{G}$-globulin was made from Fraction II protein (19), and radiolabeled rabbit antibodies from rabbit gamma globulins precipitated from rabbit antisera by $33 \%$ ammonium sulfate. ${ }^{131}$ Iodine was used 4 in the method described by Helmkamp and co-workers (20). After passage of the labeled preparations through Dowex 1-X-4 exchange resin and dialysis against $0.15 \mathrm{M} \mathrm{NaCl}$ for 24 hours, over $99 \%$ of the iodine was precipitable with trichloroacetic acid (TCA), and the calculated level of iodination was one to two atoms of iodine per molecule of protein. These preparations were used in Ouchterlony immunodiffusion analyses; the slides were washed with $0.15 \mathrm{M} \mathrm{NaCl}$ containing $0.5 \mathrm{M}$ glycine, then distilled water. The dried slides were developed against Kodak No Screen film after exposures varying from 1 to 24 hours.

Preparation of Fc- and Fab-fragments. After zone electrophoresis (21) in Pevikon with $0.075 \mathrm{M}$ barbital at $\mathrm{pH} 8.6$, the slow half of $\gamma \mathrm{G}$-globulin was separated and digested by $1 \%$ by weight papain at $37^{\circ}$ for 6 hours. The digested protein underwent electrophoresis again in Pevikon, and the fast $\left(F_{c}\right)$ and slow $(F a b)$ areas were identified by immunodiffusion analysis. There was little or no overlap of these areas. Slow fragment $F\left(a b^{\prime}\right)_{2}$ was obtained from $\gamma \mathrm{G}$-globulin digested for 24 hours with $1 \%$ pepsin at $\mathrm{pH}$ 4.0. The Fc-fragment showed, as expected, strong reactivity with rabbit antiheavy $(\gamma)$ chain sera but not with antilight chain sera, it sedimented in sucrose density gradient ultracentrifugation as a 3.5 to

${ }^{4}$ We wish to thank Dr. Irving Spar for his help in labeling these proteins.
4.0 $\mathrm{S}$ protein, and it was devoid of binding sites for specific antigen. The $F a b$ and $F\left(a b^{\prime}\right)_{2}$ fragments contained components reactive with antilight chain sera; they sedimented at 3.5 to $4.0 \mathrm{~S}$ and 4.5 to $5.0 \mathrm{~S}$, respectively, and were capable of specific binding with antigen.

Preparation of heavy and light chains. One vol of 2 -mercaptoethanol was added to 70 vol of $\gamma \mathrm{G}$-globulin ( $2 \mathrm{mg}$ Fraction II nitrogen per $\mathrm{ml}$ ) with vigorous swirling at room temperature. After 1 hour an equal volume of $0.4 \mathrm{M}$ iodoacetamide was added and another hour allowed for reaction. After dialysis against $1 \mathrm{M}$

\section{TABLE II}

Immunodiffusion coefficients of urinary $\gamma$-globulins and of serum $\gamma$ G-globulin and Fc-fragment with an antiheavy $(\gamma)$ serum

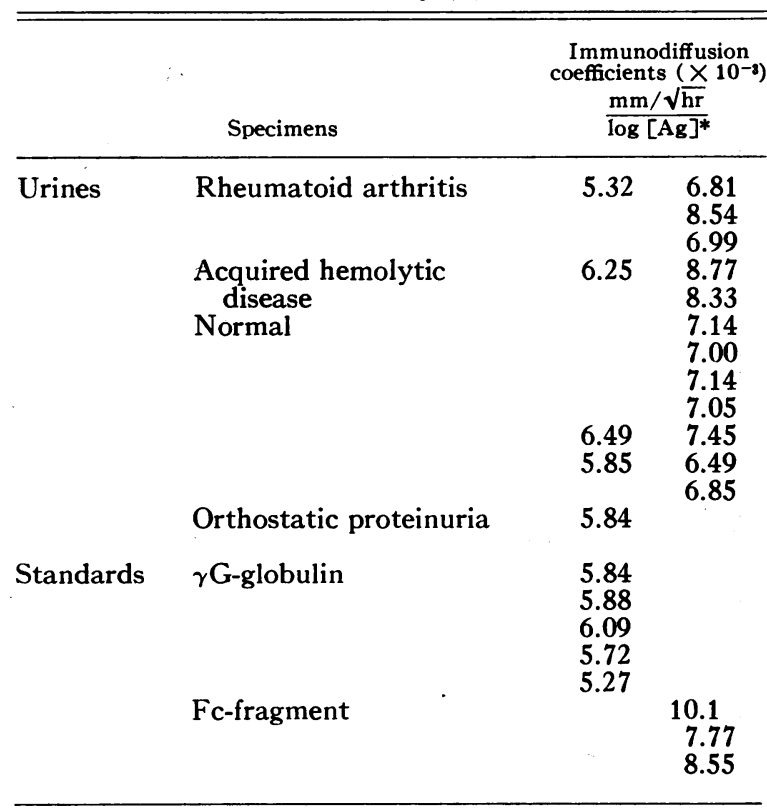

*Ag = antigen. 
acetic acid, the heavy and light chains were separated by Sephadex G-100 filtration in $1 \mathrm{M}$ acetic acid (16).

Sucrose density gradient ultracentrifugation (22). Gradients were prepared with a Buchler Densigrad, and centrifugation was carried out in a model L Spinco with an SW 39 head at 35,000 rpm for 18 to 20 hours. The tubes were sampled from the bottom. Sedimentation coefficients of test materials could be estimated by their positions relative to marker proteins aldolase (7.8 S), HSA (4.6 S), or EA (3.6 S).

Diffusion coefficients. Diffusion coefficients were estimated from immunodiffusion data. As noted by Neff and Becker (23), when varying concentrations of pro- teins are examined in agar diffusion analyses and the distances migrated are plotted against the square root of time, a family of curves is obtained. The individual slopes $d / \sqrt{t}$ of these curves, when plotted against the log antigen concentration, give a new slope $(d / \sqrt{t}) /(\log$ [Ag]), which is proportional to the square root of the diffusion coefficient of the antigen. In this paper we refer to this value as the immunodiffusion coefficient.

When the immunodiffusion coefficients of known $\gamma \mathrm{G}$ globulin or Fc-fragment were determined, the plots of $(\mathrm{d} / \sqrt{\mathrm{t}}) /(\log [\mathrm{Ag}])$ gave straight lines only at lower concentrations of antigen. We assumed that at higher concentrations lack of linearity was due to heterogeneity

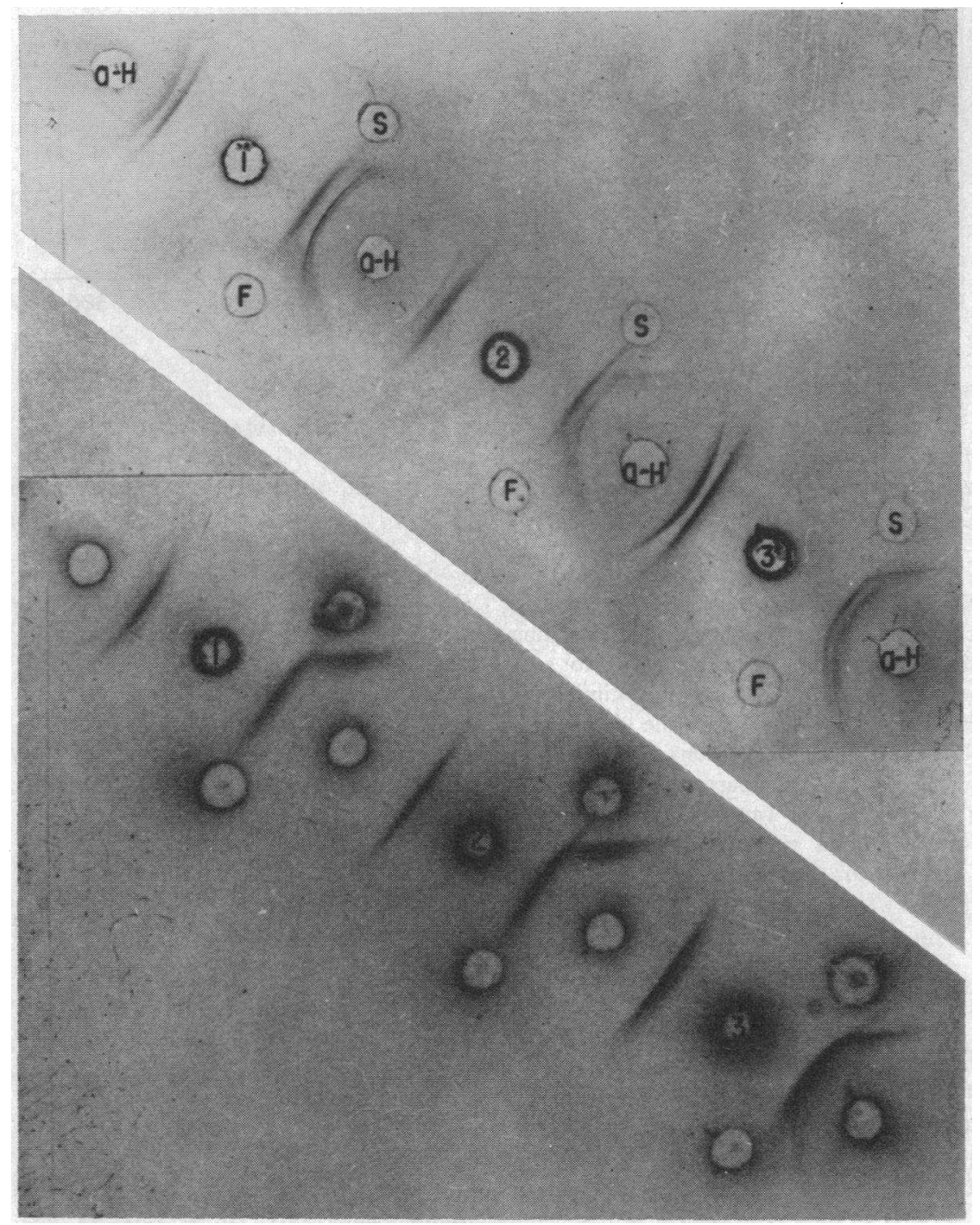

Fig. 2. Top, Reactions in agar of three Concentrated URine Samples $(1,2,3)$ With AN ANTI- $\gamma$ G SERUM ABSORBED With Light Chains (A-H). Fc (F) and Fab (S) preparations are in side wells. BotTom, RAdioAutograph OF THE ABOve SLIDE AFTER WASHING IN BUFFER AND EXPOSURE To ${ }^{181}$ I-LABELED ANTI-BENCE JONES ( $\kappa$ ) TO IDENTIFY Which OF THE PRECIPITIN LINES CONTAINED $\kappa$ CHAINS. 


\section{IMMUNODIFFUSION OF FC FRAGMENT AND YG GLOBULIN IN AGAR}

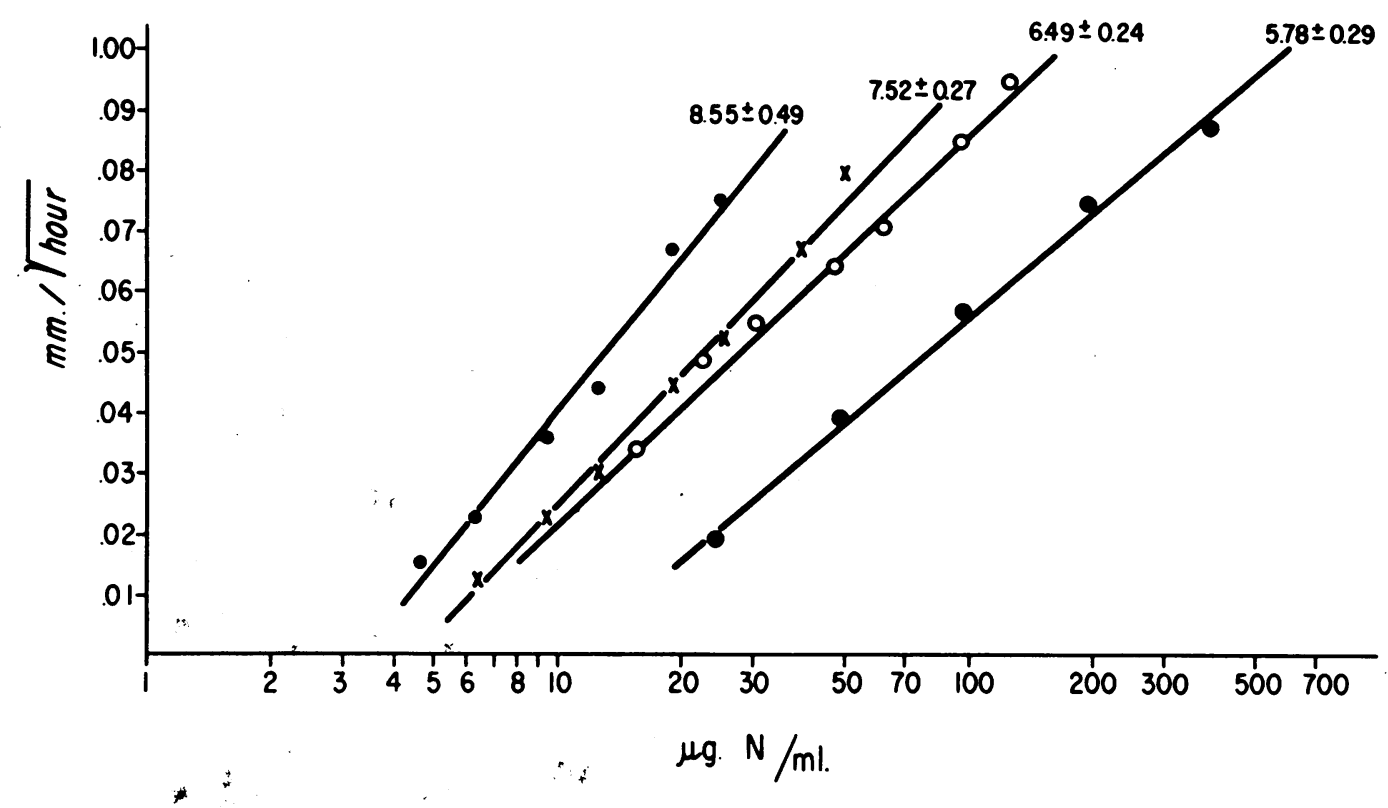

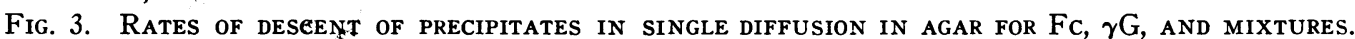
Antiserum: antiheavy $(\gamma)$ chain. From left to right: Fc; $1: 1 \mathrm{Fc}-\gamma \mathrm{G} ; 1: 4 \mathrm{Fc}-\gamma \mathrm{G} ; \gamma \mathrm{G}$. At the top of each curve is indicated the respective immunodiffusion coefficient, (millimeters per $\sqrt{\mathrm{ihour}}) /(\log [\mathrm{Ag}])$, calculated by the method of least squares. $\mathrm{Ag}=$ antigen.

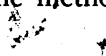

of the $\gamma \mathrm{G}$-globulin and $\mathrm{Fc}$-fragments used, i.e., to the presence of aggregates of $\gamma \mathrm{G}$-globulin, to contaminating $\gamma \mathrm{G}$-globulin in the Fc-fragment preparation, or to subtypes in the $\gamma \mathrm{G}$ system $(24,25)$. We, could minimize the influence of such "impurities" by doing the determinations at more dilute antigen concentrations. In practice, it has proved satisfactory to compare the immunodiffusion coefficient of $\gamma \mathrm{G}$ globulin (as Cohn Fraction II) with its chains and digestion products at antigen concentrations low enough to give millimeter per $\sqrt{\text { hoùr }}$ slopes of 0.080 or less.

\section{Results}

Ouchterlony double diffusion analyses of concentrated urines from normal persons in this and previous studies (9) have frequently revealed the presence of four or five lines with antibody to human $\gamma$ G-globulin (Figure 1). Two of these lines were close together near the antibody well. These lines were not seen when anti- $\gamma$-chain serum was used instead of the anti- $\gamma \mathrm{G}$ serum, and they could therefore be attributed to light chains. The other bands of precipitation, which were nearer the urine wells and were formed just as well with the anti- $\gamma$ - chain serum as with the anti- $\gamma \mathrm{G}$ serum, could be -attributed to whole $\gamma \mathrm{G}$-globulins or to heavy chain subtypes or fragments.

Initially, we made attempts to quantitate the amounts of the urinary gamma globulin components responsible for some of these lines by examining the urines in Oudin single diffusion against anti- $\gamma$, anti-BJ $\kappa$, and anti-BJ $\lambda$ sera. The standard curves used for these calculations were prepared by diffusion of known serum $\gamma \mathrm{G}$-globulins (Fraction II) and of: light chains derived from them against the anti- $\gamma$ and anti-BJ sera. For therlight chain standard curves, we assumed that there was a $2 \pi i$ ratio of $\kappa$ to $\lambda$ chains in the preparation used (26).

As seen in Table I, columns 1 and 2, the calculated mean value for $\kappa$ chains excreted in normal urines was $350 \mu \mathrm{g} N$ per 24 hours, and the $\lambda$ chain value was $180 \mu \mathrm{g} \mathrm{N}$. Although the mean ratio of $\kappa$ to $\lambda$ chains in the urines agreed with the $2: 1$ ratio that has been described for serum $\gamma \mathrm{G}$ globulins (26), the individual variation around 
this average was very wide. The summed value of $530 \mu \mathrm{g}$ light chain nitrogen per 24 hours ( $\kappa$ plus $\lambda$ ) represents more than half the gamma globulin known to be present in normal urines from other studies (9).

The amounts of $\gamma \mathrm{G}$-globulin calculated to be present from the diffusion studies were surprisingly high (last column). These calculated amounts would have suggested that more than half the urinary gamma globulin was intact $(7 \mathrm{~S})$ $\gamma \mathrm{G}$-globulin, but this conflicted with reports $(1,3$, $5)$ which have indicated that no more than 5 to $10 \%$ of the urinary gamma globulin is $7 \mathrm{~S}$. It thus seemed likely that use of intact $\gamma \mathrm{G}$-globulin as the standard against which the diffusion values for urine against the anti- $\gamma$-chain serum were calculated was incorrect, i.e., that $7 \mathrm{~S} \gamma \mathrm{G}$-globulin was not the principal determinant of the leading edge of the band precipitating with the anti- $\gamma$ serum.

When urines were examined in varying concentrations against an anti- $\gamma$ serum, immunodiffusion coefficients were obtained for the urinary heavy $(\gamma)$ component as shown in Table II. Most urines gave one diffusing band, ${ }^{5}$ but some gave two. The coefficients for the heavy component were usually significantly higher (last column in the Table) than those of the $\gamma \mathrm{G}$-globulin standards, indicating that it was smaller than $\gamma \mathrm{G}$-globulin. Two precipitin bands were seen in the urines on four occasions; on two of these occasions the extra (and slower) bands had coefficients that approximated those of the $7 \mathrm{~S} \gamma \mathrm{G}$-globulin standards. In urine from a patient with orthostatic proteinuria, a single band, which diffused like $7 \mathrm{~S} \gamma \mathrm{G}$-globulin, was seen.

To determine whether the urinary heavy $(\gamma)$ chain component was in a molecule that also had light chains in it, we carried out radioimmunodiffusion studies. Three different normal human urines were examined by Ouchterlony double diffusion analysis with an anti- $\gamma$-chain serum and compared with Fc- and Fab-fragments (upper portion of Figure 2). As can be seen in the upper Figure, two lines of precipitation developed between each urine and the anti- $\gamma$ serum. The line closer to the antibody well was markedly concave

5 Urines that gave two or three distinct bands in double diffusion analysis with anti- $\gamma$ sera often exhibited only one or two bands in single diffusion. toward the well, as would be expected if the urinary component precipitating in this line was smaller than the $7 \mathrm{~S}$ rabbit antibody (27). After the lines were fully developed, the slide was washed and all wells were filled with a ${ }^{131} \mathrm{I}$-labeled anti-BJ $\kappa$ preparation. Radioautography (lower portion of Figure 2) revealed that only the straight line became radioactive. Thus, the straight line contained light chains and was assumed to represent urinary $7 \mathrm{~S} \gamma$-globulin, or at least half molecules containing one heavy chain and one light chain. The curved line was devoid of light chains.

Further diffusion studies were then carried out to determine whether mixtures of $\gamma \mathrm{G}$-globulin and $\mathrm{Fc}$-fragment would give intermediate immunodiffusion coefficients. Figure 3 illustrates that the immunodiffusion coefficients of the mixtures changed from that of the Fc-fragment alone towards that of $\gamma \mathrm{G}$-globulin alone. The intermediate values of the mixtures were like those encountered in the urines.

Since both $7 \mathrm{~S} \gamma \mathrm{G}$-globulin and an Fc-like frag-

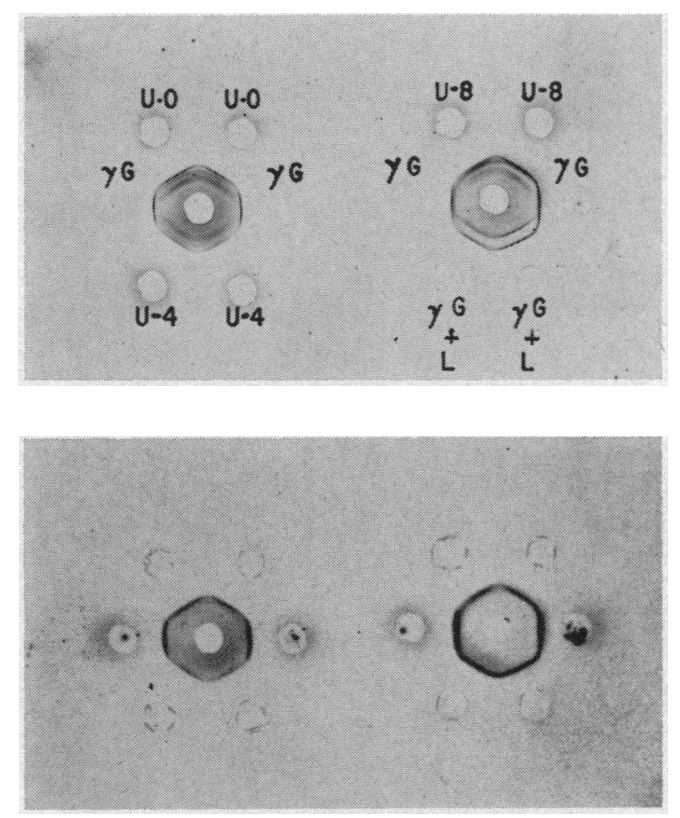

Fig. 4. TOP, REACTIONS IN AGAR OF FRESH URINES CONTAINING ADDED $\gamma$ G-GLOBULIN ${ }^{131}$ I KEPT 0,4 , AND 8 HOURS AT $37^{\circ} \mathrm{C}$ BEFORE CONCENTRATION AND ANALYSIS (U-0, U-4, AND U-8). $\gamma$ G-globulin- ${ }^{131} I$ plus unlabeled light (L) chains served as a control at the bottom right. Anti$\gamma \mathrm{G}$-globulin was in the center well. BotTom, RADIoAutoGRAPH OF THE ABOVE SLIDE INDICATING FAILURE OF DETECTABLE RADIOACTIVITY TO APPEAR AMONG THE FREE LIGHT CHAINS. 
ment thus appear to be present in urine, the quantitative diffusion data obtained with the anti- $\gamma$ serum in Table I were recalculated on the basis of an Fc standard curve. The total quantity of $\gamma \mathrm{G}$ globulin plus $\mathrm{Fc}$-like fragment in the urine generally lies somewhere between the two values given in the Table (cf. also Figure 3). A somewhat better estimate of the total and relative quantities of $\mathrm{Fc}$-like fragment and $\gamma \mathrm{G}$ in any given urine can be obtained when the urine has been examined in several dilutions, so that the immunodiffusion coefficient for the particular urinary determination is also known (Table II) and a proper standard curve (Figure 3 ) is chosen for the estimation. The data in Table II and Figure 3 suggest that it is common for there to be nearly equal quantities of Fc-like fragment and $\gamma \mathrm{G}$-globulin in urines (coefficients above 7 ) and that occasionally the Fclike fragment may predominate (coefficients near
8.5). If one assumes that, on the average, there is an equal quantity of Fc-like fragment and $7 \mathrm{~S}$ $\gamma \mathrm{G}$-globulin present in urines, it can be calculated that $7 \mathrm{~S} \gamma \mathrm{G}$-globulin and Fc-like fragment each may compose about $15 \%$ of the sum total of $7 \mathrm{~S}$ $\gamma \mathrm{G}$-globulin, Fc-fragment, and free light chains.

Although Rowe and Soothill (7) and Hanson and Tan (28) had presented evidence that gamma globulin is not broken down in urine by urinary enzymes, independent assessment of this possibility was made. To a freshly collected pool of normal urines was added radioiodinated $\gamma \mathrm{G}$-globulin. The pool was then divided into three aliquots. We immediately placed one in the cold and began dialysis against Carbowax to concentrate it for subsequent immunodiffusion analysis. The other two were incubated for 4 to 8 hours at $37^{\circ} \mathrm{C}$. Then they were transferred to the cold for concentration and analysis. Figures 4 and 5 show the
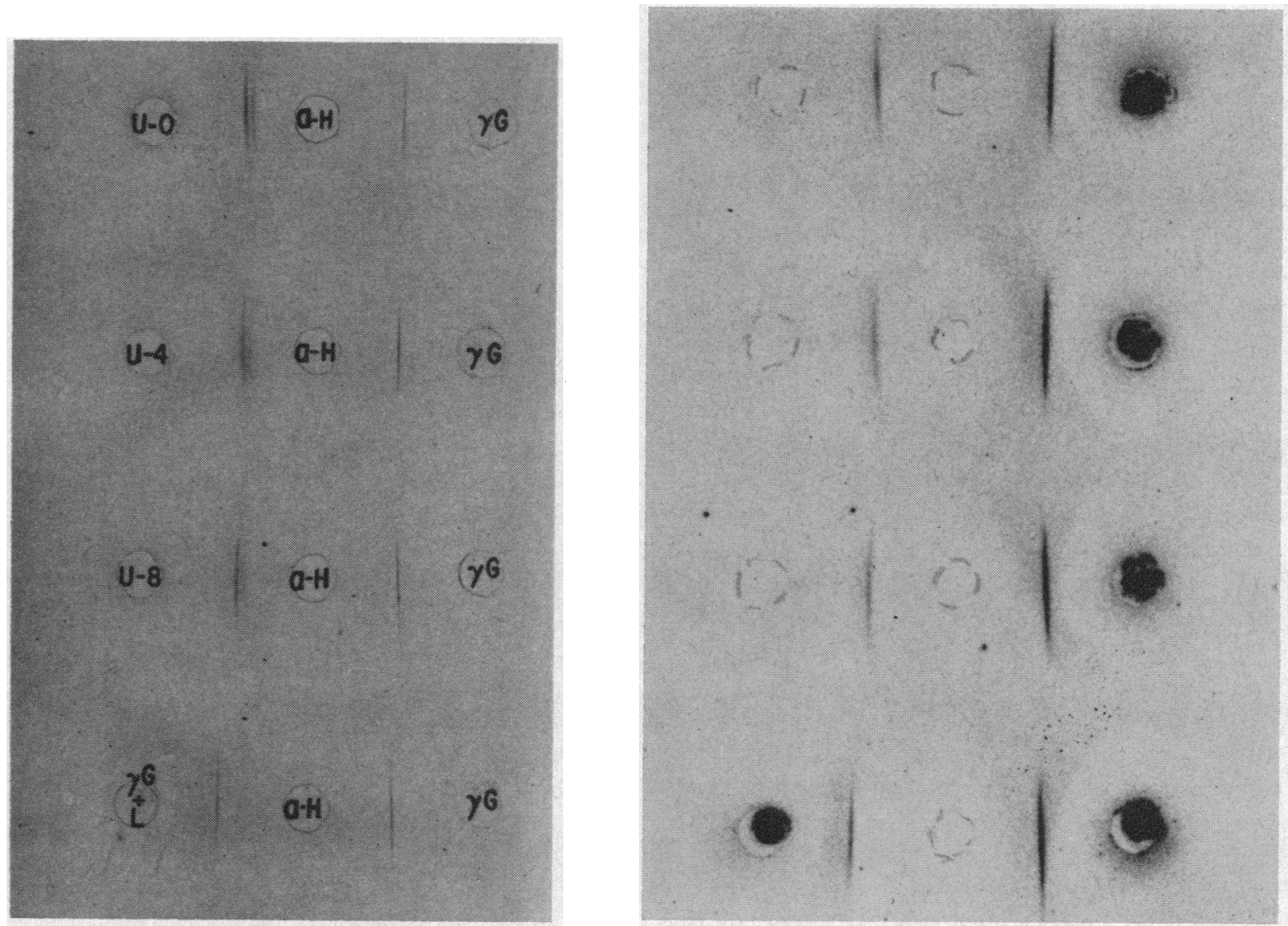

Fig. 5. Left, REACtIONS IN AGAR OF FRESH URINES CONTAINING ADDED $\gamma$ G-GLOBULIN- ${ }^{131}$ I KePt 0 , 4 , AND 8 HOURS at $37^{\circ} \mathrm{C}$ Before CONCENTRATION AND ANALYSis (U-0, U-4, AND U-8). $\quad \gamma$ G-globulin- ${ }^{131} \mathrm{I}$ plus unlabeled light chains are at the bottom. Antiheavy $(\gamma)$ chains (a-H). Right, RAdioautograph of the ABove SLIDE INDiCATING FaILURE OF DETECTABLE RADIOACTIVITY TO APPEAR IN THE HEAVY $(\gamma)$ CHAIN FRAGMENT. 
TABLE III

Specific activities of urinary $\gamma$-globulins isolated by immunoprecipitation

\begin{tabular}{|c|c|c|c|c|c|}
\hline & \multirow{2}{*}{$\underset{\text { present* }}{\gamma \text {-Globulins }}$} & \multicolumn{2}{|c|}{ Antiheavy $(\gamma)$} & \multicolumn{2}{|c|}{ Antilight } \\
\hline & & Pptn. & $\mathrm{cpm} / \mathrm{OD} t$ & Pptn. & $\mathrm{cpm} / \mathrm{OD} \dagger$ \\
\hline $\begin{array}{l}\text { Pool } 1 \\
\text { Pool } 2 \\
\text { Pool } 3\end{array}$ & 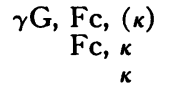 & $\begin{array}{l}4+ \\
2+ \\
\text { Trace? }\end{array}$ & $\begin{array}{l}0 \\
0 \\
0\end{array}$ & $\begin{array}{l}1+ \\
6+ \\
4+\end{array}$ & $\begin{array}{l}195 \\
162 \\
140\end{array}$ \\
\hline
\end{tabular}

* See Figure 7.

t Optical densities are calculated from the sums of the individual concentrations of $\gamma$-globulins in each fraction in the quantitation diffusions of Figure 7, using for comparison appropriate antigens with the standard antisera.

patterns obtained when these aliquots were examined after diffusion against anti- $\gamma \mathrm{G}$ or anti- $\gamma$ sera. In each instance, comparison was made with the behavior of a control mixture of iodinated $\gamma \mathrm{G}$-globulin mixed with noniodinated light chains. Radioactivity did not appear in the light chain lines in Figure 4 (the inner lines nearer the antiserum well), nor in the line due to the heavy $(\gamma)$ chain fragment in Figure 5. In both instances, only the line corresponding to whole $\gamma \mathrm{G}$ globulin appeared radioactive. ${ }^{6}$

Ultracentrifugal analyses in sucrose density gradients have been performed on urines from a number of patients and from normal persons. In Figure 6 are shown the results of one such study on concentrated pooled urine from male hospital employees. After centrifugation the fractions were examined in agar against specific antisera in single diffusion (quantitative) and double diffusion (qualitative) analyses. Precipitation was seen with anti- $\gamma$ serum in all regions from 7 to

${ }^{6}$ Although these data indicate no significant breakdown of $\gamma \mathrm{G}$-globulin in the urine under the conditions employed, this may not hold for other conditions. In one experiment in our studies in which urines were dialyzed against acetic acid before analysis, all immunological evidence of the presence of $\gamma$-globulins disappeared. The acid conditions of this experiment may have allowed activation of uropepsinogens (29).

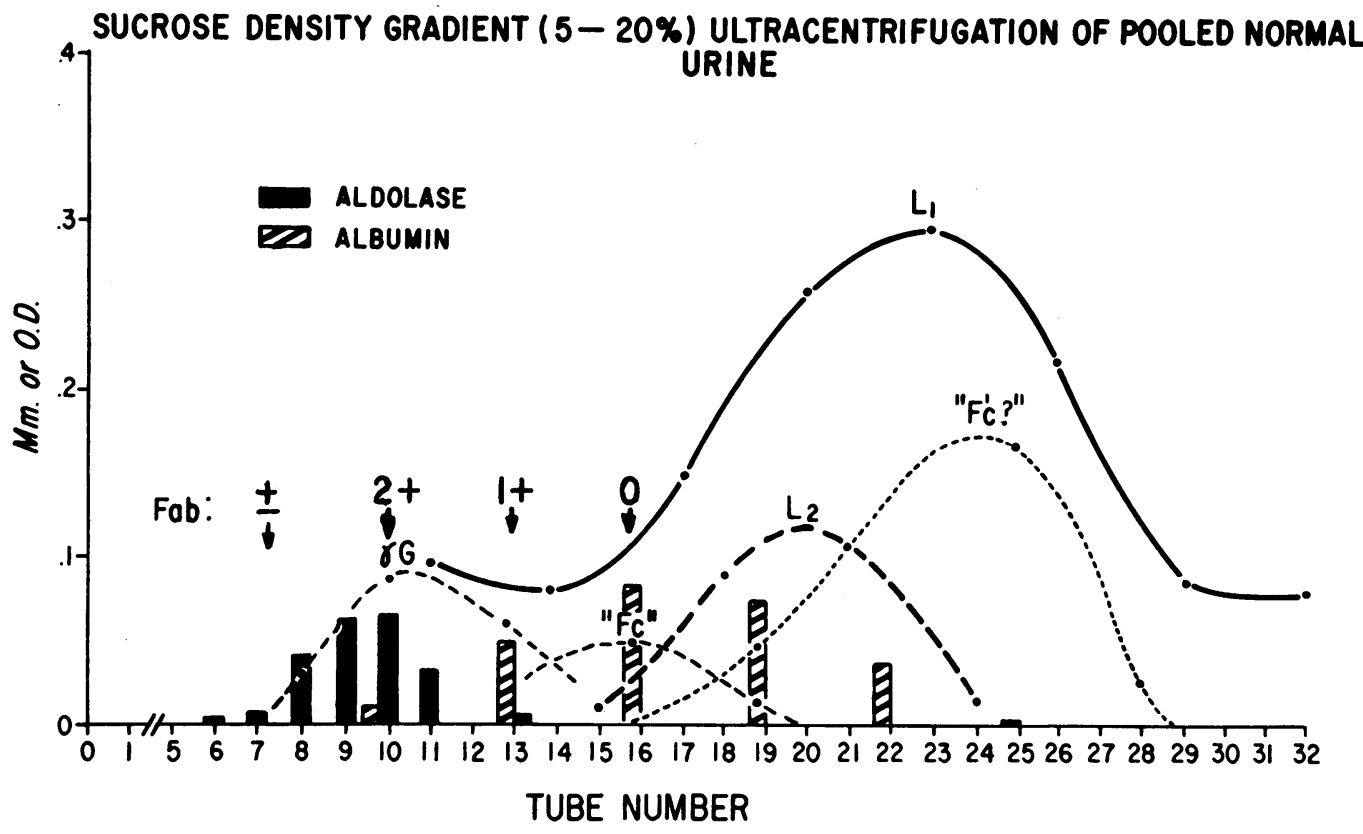

Fig. 6. Distributions of URine components in zonal centrifugation. Components reactive with an antiheavy $(\gamma)$ chain serum are labeled $\gamma \mathrm{G}$, " $F c$," and " $F$ 'c?" Those reactive with anti-Bence Jones sera are labeled $L_{1}(\kappa)$ and $L_{2}(\lambda)$, respectively. The curves were determined by distances of migration in single diffusion analyses. Those fractions reactive with anti-Fd-fragment serum are designated Fab, since they were limited to the 6 to $8 \mathrm{~S}$ region where they are attributable to the Fab portion of $7 \mathrm{~S}$ $\gamma \mathrm{G}$-globulin. Aldolase $(7.8 \mathrm{~S}$ ) was an added marker. Albumin (4.6 S) was a normal urinary component. The total areas under the curves cannot generally be taken to represent relative quantities of the various components, as no account is taken of differences in diffusion coefficients of antigens or quantities of reacting antibodies. 


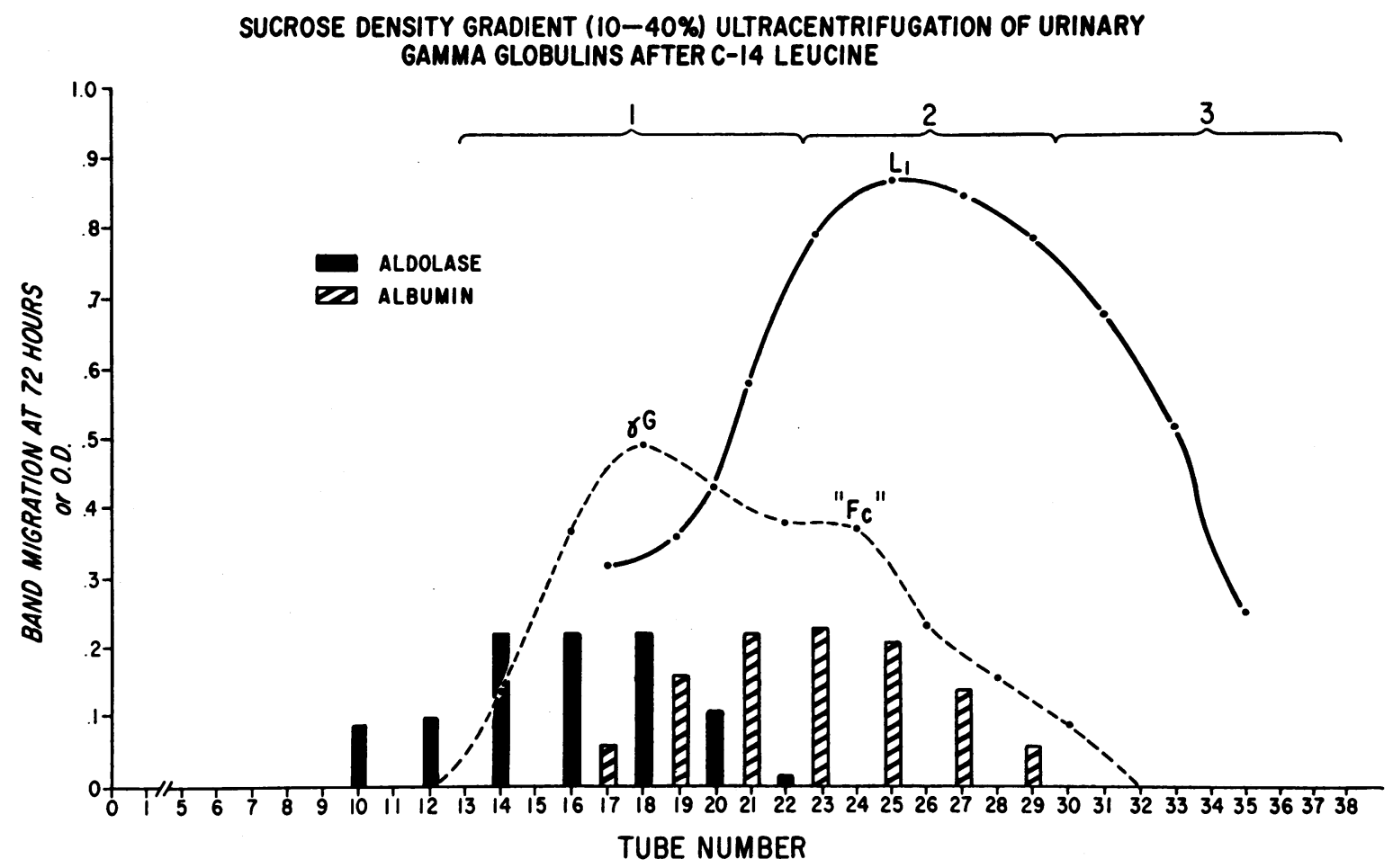

Fig. 7. ZoNal SEPARATION BY ULTRACENTRIFUgation OF URINARY GAMMA GLOBULINS PREVIOUSLY ISOLATED BY PREparative DEAE chromatography. Pools 1,2 , and 3 were made as indicated. Lambda chains were not assayed. See legend to Figure 6.

$2 \mathrm{~S}$. In the $7 \mathrm{~S}$ region the precipitates became radioactive when ${ }^{131} \mathrm{I}$-labeled anti-BJ serum was added to the Ouchterlony analyses, consistent with the assumption that intact $(7 \mathrm{~S}) \gamma \mathrm{G}$-globulin was precipitating in this region. Fractions from the $7 \mathrm{~S}$ region also precipitated, as expected, with an anti-Fd-fragment serum. In the 3 to $5 \mathrm{~S}$ region, however, the precipitates formed with the anti- $\gamma$ serum failed to become radioactive in the presence of a ${ }^{131} \mathrm{I}$-labeled anti-BJ serum, and there was no precipitation with anti-Fd-fragment serum. The protein in the 3 to $5 \mathrm{~S}$ region has characteristics, therefore, of Fc-fragment. The precipitates formed in the 2 to $3 \mathrm{~S}$ region also failed to give evidence of light chains or Fd-fragment and were very much fainter than those in the 3 to $5 \mathrm{~S}$ region. The 2 to $3 \mathrm{~S}$ protein, which may be a urinary $\mathrm{Fc}^{\prime}(13,30)$, was not seen in studies of several other urines, possibly for quantitative reasons.

Studies were carried out to determine whether the urinary component sedimenting as Fc-fragment is an anabolic or catabolic product of gamma globulin metabolism. A patient with rheumatoid arthritis was given $100 \mu \mathrm{c}$ of leucine- $1-{ }^{14} \mathrm{C}$. The urines were collected quantitatively for the next 24 hours, the period during which maximal incorporation of the labeled amino acid into urinary gamma globulins occurs (9). The urine sample was concentrated with Carbowax and passed through a DEAE cellulose column at $0.0175 \mathrm{M}$ phosphate and $\mathrm{pH}$ 6.3. The gamma globulins thereby obtained $(5,9)$ were then submitted to sucrose density gradient ultracentrifugation; the pattern exhibited in Figure 7 was found. The tubes in the 4 to $7 \mathrm{~S}$, the 3 to $4 \mathrm{~S}$, and the 2 to $3 \mathrm{~S}$ areas of the centrifuge run were pooled separately. To the pooled samples we added excesses of the rabbit anti- $\gamma$ serum to precipitate all protein containing heavy chain; to the supernatant we added anti- $\gamma \mathrm{G}$ serum to precipitate the residual light chains. The precipitates were packed by centrifugation and then dissolved in 1 or $2 \mathrm{ml}$ of $\mathrm{Hy}-$ amine $(9,31)$. The samples were added to $10 \mathrm{ml}$ of PPO-POPOP [2,5-diphenyloxazole-1, 4-bis-2(5-phenyloxazolyl) benzene] and counted in a liquid scintillator. The results indicated in Table 


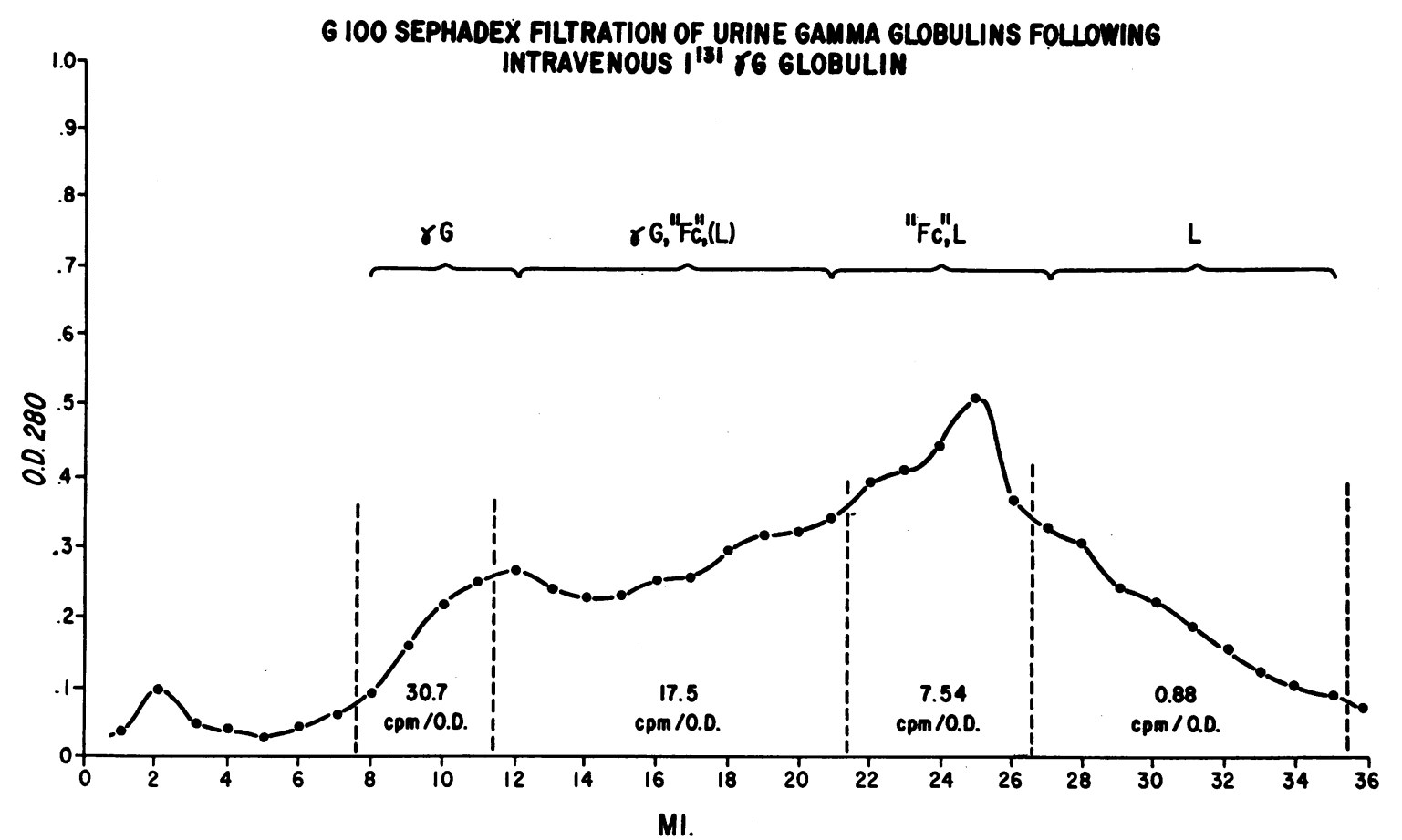

Fig. 8. Specific radioactivities in Sephadex filtration fractions of URinary gamma globulins previously ISOlated BY PREPARATIVE DEAE Chromatography. There is significant radioactivity in the pool containing FCfragment plus light chains but none in the pool containing light chains alone. Maximal radioactivity was seen in the pool containing $\gamma \mathrm{G}$-globulin alone. The pools were constructed on the basis of their contents of gamma globulin components, as indicated by their immunodiffusion patterns with specific antisera.

TABLE IV

Urinary excretion of $\gamma$-globulins in agammaglobulinemic patients before and after treatment with $\gamma G$-globulin

\begin{tabular}{|c|c|c|c|c|c|c|c|c|c|}
\hline \multirow{2}{*}{$\begin{array}{c}\text { Patient: } \\
\text { Type }\end{array}$} & \multicolumn{3}{|c|}{ M.C.* } & \multicolumn{3}{|c|}{ L.P.† } & \multicolumn{3}{|c|}{ D.w.t } \\
\hline & Day & Excretion & ID\& & Day & Excretion & ID\& & Day & Excretion & ID\& \\
\hline & & $\mu g N / d a y$ & & & $\mu g N / d a y$ & & & $\mu \mathrm{g} N /$ day & \\
\hline $\begin{array}{l}\text { Heavy }(\gamma) \\
\kappa \\
\lambda\end{array}$ & -13 & $\begin{array}{r}0 \\
33 \\
14\end{array}$ & - & -1 & $\begin{array}{r}0 \\
23 \\
7\end{array}$ & & $-(1-3)$ & $\begin{array}{r}21 \\
0 \\
0\end{array}$ & \\
\hline $\begin{array}{l}\gamma \\
\kappa \\
\lambda\end{array}$ & -12 & $\begin{array}{r}0 \\
39 \\
15\end{array}$ & & & & & & & \\
\hline$\gamma$ & +5 & 30 & $9.80 \pm 0.52$ & +1 & 105 & $10.6 \pm 0.43$ & $+(1-3)$ & $\begin{array}{l}14 \\
36\end{array}$ & $\begin{array}{r}8.13 \pm 0.42 \\
11.3 \pm 0.78\end{array}$ \\
\hline $\begin{array}{l}\kappa \\
\lambda\end{array}$ & & $\begin{array}{l}52 \\
25\end{array}$ & & & $\begin{array}{l}38 \\
15\end{array}$ & & & $\begin{array}{r}11 \\
0\end{array}$ & \\
\hline $\begin{array}{l}\gamma \\
\kappa \\
\lambda\end{array}$ & +10 & $\begin{array}{l}35 \\
41 \\
19\end{array}$ & & +4 & $\begin{array}{r}83 \\
20 \\
9\end{array}$ & & & & \\
\hline
\end{tabular}

* A 48-year-old female; serum $\gamma \mathrm{G}$ was $<10 \mathrm{mg}$ per $100 \mathrm{ml}$.

+ A 39-year-old male; serum $\gamma \mathrm{G}$ was $<10 \mathrm{mg}$ per $100 \mathrm{ml}$.

I A 9-year-old male; serum $\gamma \mathrm{G}$ was $246 \mathrm{mg}$ per $100 \mathrm{ml}$. This patient had been on $\gamma \mathrm{G}$-globulin therapy; the last injection was given 8 days before this serum determination.

$\S$ Immunodiffusion coefficient $\left(\times 10^{-3}\right)$. 
III were found. Measurable radioactivity was completely restricted to samples containing free light chains. Thus, the urinary Fc-like protein, unlike urinary light chains $(5,9)$, could not be shown by this method of analysis to be an anabolic product of gamma globulin metabolism.

The same patient was given an intravenous injection of $\gamma \mathrm{G}$-globulin labeled with 1.5 atoms ${ }^{131} \mathrm{I}$ per molecule. The urinary proteins were collected over a 3-day period and the collections were pooled. The gamma globulins were separated by DEAE chromatography and filtered through Sephadex G-100 (Figure 8). After preliminary identification of the location of the various gamma globulin components in the effluents by Ouchterlony analysis, pools were made, concentrated, and divided for counting and for analysis by sucrose density gradient ultracentrifugation. The latter confirmed the distributions of gamma globulin components indicated by the initial Ouchterlony analyses and illustrated in the Figure. The highest counts of radioactivity were identified in the pools (8-11 and 12-21) containing $\gamma \mathrm{G}$-globulins. Lesser but significant counts were found in the region containing the Fc-like fragment and light chains (pool 22-26), whereas the pool (2735 ) containing only light chains was free of counts. The results confirmed, reciprocally, those obtained with leucine- ${ }^{14} \mathrm{C}$ (cf. also 5, 9).

Three patients with severe hypogammaglobulinemia were examined before and after administration of therapeutic amounts of $\gamma \mathrm{G}$-globulin $(0.1$ $\mathrm{g}$ per $\mathrm{kg}$ body weight). The urinary gamma globulins measurable in 24-hour specimens before and after the injections are indicated in Table IV. These were calculated as Fc-fragments and free light chains, respectively. In each instance it is clear that there was a significant increment in quantity of the urinary Fc-like fragment excreted. The immunodiffusion coefficients in all three urines were like those of Fc-fragment plus, in patient D.W., a still smaller component. In L.P. the increase in Fc-like fragment was sufficient to put the 24-hour excretion into the normal range (see Table I). A sucrose density gradient ultracentrifugation of a post-treatment urine from L.P. is illustrated in Figure 9. Very little $7 \mathrm{~S} \gamma \mathrm{G}$ globulin appeared to be present in this specimen.

There was a slight increase in the quantities of light chains in the post-treatment urines in all

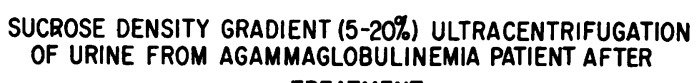
TREATMENT

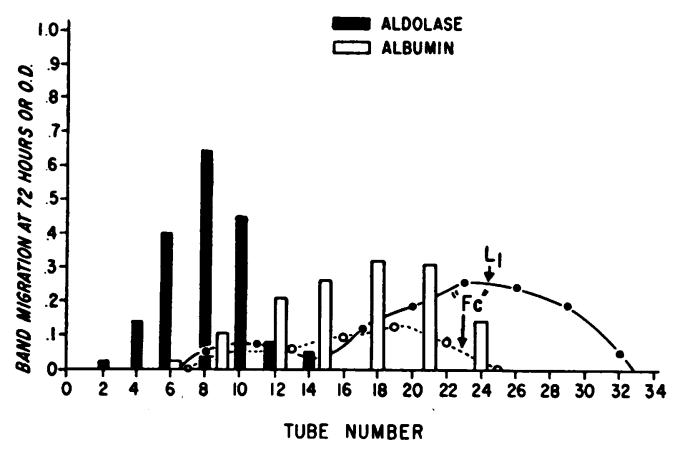

Fig. 9. URINARY GaMma globulins of POOLED URINES FROM PATIENT L.P. 2 TO 5 DAYS AFTER THERAPEUTIC ADministration of $\gamma$ G-Globulin. Preliminary separation of the gamma globulins was performed by DEAE chromatography. Lambda chains were not assayed. See legend to Figure 6.

three patients, but these quantities remained very low relative to normal values.

\section{Discussion}

Evidence has been presented by Stevenson (5) and by Gordon, Eisen, and Vaughan (9) that light chains of the urine are derived, at least predominantly, from an anabolic phase in gamma globulin metabolism. The current data indicate that an Fc-like fragment is also present in normal urine, a finding that has recently been reported independently by Turner and Rowe (32). The evidence to support belief that this Fc-like fragment is a catabolic rather than an anabolic product of serum $\gamma$ G-globulin metabolism is impressive, though perhaps still somewhat incomplete. Failure of leucine- ${ }^{14} \mathrm{C}$ to appear in the urinary Fc-like protein during the first 24 hours after its parenteral administration (Table III) may be better interpreted in terms of the longer persistence of $\mathrm{Fc}_{\mathrm{c}}$ in the circulation and the lesser rate of its delivery to the urine, as compared with light chains $(5,9$, $33,34)$. On the other hand, parenterally administered $\gamma \mathrm{G}$-globulin gave rise to $\mathrm{Fc}$-fragment in the urine in several studies (Figure 8 and Table IV). It may be argued that the purified $\gamma \mathrm{G}$-globulin (Fraction II) used for the parenteral administrations in these studies was not normal, since it had been exposed to various denaturing influences during its isolation and therefore was unusually 
susceptible to the host's catabolic systems. By the same token, the Fc-like component normally present in urines may be an excretion product from autologously denatured $\gamma \mathrm{G}$-globulin.

The Fc-like component normally present in urine resembles in some respects the component described by Franklin and associates (11) and Osserman and Takatsuki (12) in patients with "H chain disease." Franklin and associates (11) suggested that the $\gamma$-chain component in " $\mathrm{H}$ chain disease" may be derived from the anabolic side of $\gamma \mathrm{G}$-globulin metabolism, but the studies they offered in support of this were limited. The strongest evidence presented was the rate of elimination of injected radioactively labeled normal $\gamma \mathrm{G}$-globulin. Failure of the label to appear in large quantity in the urine of their patient, who was excreting large amounts of the abnormal $\gamma$-chain component, was rightly taken to indicate that normal serum $\gamma \mathrm{G}$-globulin was not a source for the urinary protein. Their data did not, however, indicate that the urinary protein could not have been a product of degradation of abnormal quantities of free heavy chains in the tissues before they reached the circulation.

The suggestion in the present findings that urinary $\mathrm{Fc}$-like fragment normally derives from catabolism of $\gamma \mathrm{G}$-globulin is significant in relation to current theories of $\gamma \mathrm{G}$-globulin structure. The six chain theory $(35,36)$ has been derived in part from Franklin's observations on the supposed anabolic nature of the urinary product in heavy chain disease. This interpretation and the theoretical extrapolation from it seem worthy of reappraisal.

The sedimentation coefficient for normal urinary Fc-like fragment could be estimated from the sucrose density gradient ultracentrifugation data by the method of Martin and Ames (37). The diffusion coefficient could be estimated from the immunodiffusion data by the method of Neff and Becker (23). Urinary Fc-like fragment could be assigned an $\mathrm{S}_{20, \mathbf{w}}$ (sedimentation coefficient corrected to $20^{\circ} \mathrm{C}$ in water) of approximately 4 . The diffusion constant, calculated from an average immunodiffusion coefficient for the Fc of $9.51 \times$ $10^{-3}$ (millimeter per $\left.\sqrt{\text { hour }}\right) /(\log$ micrograms $\mathrm{N}$ per milliliter) and for $\gamma \mathrm{G}$ of $5.76 \times 10^{-3}$ was $10.6 \times$ $10^{-7} \mathrm{~cm}^{2}$ per second. The molecular weight of the urinary $\mathrm{Fc}$-like fragment from these data and from an assumed partial specific volume of 0.74 is 35,000 . In their more precise analysis of the heavy chain component from patient $\mathrm{Cr}$ with heavy chain disease, Franklin and co-workers found a molecular weight of 50,000 (11).

Because of the reports $(28,38,39)$ of antibody activity in low molecular weight (1.2 to $3 \mathrm{~S}$ ) components in the urine, an attempt has been made to find light gamma globulin molecules containing both light and heavy chain components. By radioimmunodiffusion analyses of sucrose density gradient fractions, none of the urinary gamma globulin components lighter than $7 \mathrm{~S}$ could be shown to contain both light and heavy $(\gamma)$ chain components. Furthermore, no protein in any urinary fraction lighter than $7 \mathrm{~S}$ could be precipitated with an anti-Fd serum. Assuming the claims $(28,38,39)$ for light antibody are valid, these failures may mean that the systems employed in the present study are insensitive, or that light antibodies do not contain both light and heavy $(\gamma)$ chain components. Further studies are needed in this area.

Although Fc-like fragment can be detected in the urine rather easily, corresponding quantities of a free Fab-fragment have not been found. Gitlin, Kumate, Urrusti, and Morales (33) found that the $\mathrm{t}_{\frac{1}{2}}$ of labeled Fab injected intravenously in man was extremely short, whereas that of intravenously injected Fc-fragment was quite long. Spiegelberg and Weigle (34) made similar observations in animals and noted that radioactively labeled $\mathrm{F}\left(\mathrm{ab}^{\prime}\right)_{2}$ $(5 \mathrm{~S})$ derived from pepsin digestion behaved similarly to $\mathrm{Fab}(3.5 \mathrm{~S})$ derived fram papain digestion. The label from $\mathrm{Fab}$ or $\mathrm{F}\left(\mathrm{ab}^{\prime}\right)_{2}$ appeared in the urine, furthermore, largely in a form nonprecipitable with TCA. It seems likely, therefore, that $\mathrm{Fab}$ or $\mathrm{F}\left(\mathrm{ab}^{\prime}\right)_{2}$ may be degraded in vivo so rapidly and completely that it cannot appear in immunochemically identifiable form in the urine. That this degradation may take place in the kidney is suggested by the observations of Solomon, Waldmann, Fahey, and McFarlane (40) on the metabolism of Bence Jones proteins. These proteins are catabolized rapidly in patients with multiple myeloma who have normal renal function but not in those who have impaired renal function.

Spiegelberg and Weigle (33) found that most of the label from intravenously infused Fc-fragment also appeared in the urine in a nonprecipi- 
table form. If their data in animals are transposable to man, the measured quantities of Fc-like fragment in human urines (e.g., Tables I and IV) may represent only 5 to $20 \%$ of the total Fc product passing from the blood into the urine.

Several features about the urinary gamma globulin components in the three patients with agammaglobulinemia are of interest. First, although each of these individuals had comparable degrees of hypogammaglobulinemia, only in the child with congenital agammaglobulinemia were urinary light chains completely undetectable. The two adult patients had easily measured urinary light chain levels. These were only about one-tenth the normal average (cf. Table I), whereas the serum gamma globulin levels were less than one-hundredth the normal level. It seems possible, therefore, that the deficit in $\gamma \mathrm{G}$-globulin production in the adults may be more closely related to impairment of heavy chain than light chain production.

The amount of Fc-like fragment that appeared in the urine of the agammaglobulinemic patients after treatment was greater in proportion to the serum levels of gamma globulin than one would expect from the urinary values in normal individuals (Table I). This suggests that in the treated agammaglobulinemic individual there may be a more rapid than normal breakdown of the injected gamma globulin. The measured halflife of the injected $\gamma$ G-globulin in the serum of each of the agammaglobulinemic patients was normal or prolonged. It seems reasonable to assume that there may be breakdown of the gamma globulin at the sites of injection in the interstitial tissues by proteolytic processes called into play in response to the abnormal quantity of protein deposited there.

\section{Acknowledgments}

We are very much indebted to Mr. Frank Buettner and Mrs. Elsa Welch for their help in conducting these studies.

\section{References}

1. Webb, T., B. Rose, and A. H. Sehon. Biocolloids in normal human urine. I. Amount and electrophoretic characteristics. Canad. J. Biochem. 1958, 36, 1159.

2. Webb, T., B. Rose, and A. H. Sehon. Biocolloids in normal human urine. II. Physicochemical and immunochemical characteristics. Canad. J. Biochem. 1958, 36, 1167 .
3. Franklin, E. C. Physicochemical and immunologic studies of gamma globulins of normal human urine. J. clin. Invest. 1959, 38, 2159.

4. Stevenson, G. T. Detection in normal urine of protein resembling Bence Jones protein. J. clin. Invest. 1960, 39, 1192.

5. Stevenson, G. T. Further studies of the gamma-related proteins of normal urine. $\mathrm{J}$. clin. Invest. 1962, 41, 1190.

6. Berggård, I., and G. M. Edelman. Normal counterparts to Bence Jones proteins: free $\mathrm{L}$ polypeptide chains of human $\gamma$-globulin. Proc. nat. Acad. Sci. (Wash.) 1963, 49, 330.

7. Rowe, D. S., and J. F. Soothill. Serum proteins in normal urine. Clin. Sci. 1961, 21, 75.

8. Rigas, D. A., and C. G. Heller. The amount and nature of urinary proteins in normal human subjects. J. clin. Invest. 1951, 30, 853 .

9. Gordon, D. A., A. Z. Eisen, and J. H. Vaughan. Studies on urinary $\boldsymbol{\gamma}$-globulins in patients with rheumatoid arthritis. Arthr. and Rheum. 1966, 9, 575.

10. Freedman, M. H., and G. E. Connell. The heterogeneity of gamma-globulin in post-exercise urine. Canad. J. Biochem. 1964, 42, 1065.

11. Franklin, E. C., J. Lowenstein, B. Bigelow, and M. Meltzer. Heavy chain disease-a new disorder of serum $\gamma$-globulins. Amer. J. Med. 1964, 37, 332.

12. Osserman, E. F., and K. Takatsuki. Plasma cell myeloma: gamma globulin synthesis and structure. A review of biochemical and clinical data, with the description of a newly-recognized and related syndrome, "H ${ }^{\gamma-2}$-chain (Franklin's) disease." Medicine (Baltimore) 1963, 42, 357.

13. Edelman, G. M., J. F. Heremans, M.-Th. Heremans, and $\mathrm{H}$. G. Kunkel. Immunological studies of human $\gamma$-globulin. Relation of the precipitin lines of whole $\gamma$-globulin to those of the fragments produced by papain. J. exp. Med. 1960, 112, 203.

14. Berggård, I. On a $\gamma$-globulin of low molecular weight in normal human plasma and urine. Clin. chim. Acta 1961, 6, 545.

15. Rubinstein, H. M. Quantitative antigen analysis by the Oudin method. J. Immunol. 1954, 73, 322.

16. Fleischman, J. B., R. H. Pain, and R. R. Porter. Reduction of $\gamma$-globulins. Arch. Biochem. 1962, 98 (suppl.), 174.

17. Leddy, J. P., R. Hill, S. N. Swisher, and J. H. Vaughan. Observations on the Immunochemical Nature of Red Cell Autosensitization. Immunopathology, Third International Symposium, LaJolla, Calif. Basel, Schwabe and Co., 1963, p. 318.

18. Ouchterlony, Ö. Diffusion-in-gel methods for immunological analysis. Progr. Allergy 1958, 5, 1.

19. Cohn, E. J., F. R. N. Gurd, D. M. Surgenor, B. A. Barnes, R. K. Brown, G. Derouaux, J. M. Gillespie, F. W. Kahnt, W. F. Lever, C. H. Liu, D. Mittelman, R. F. Mouton, K. Schmid, and E. Uroma. 
A system for the separation of the components of human blood: quantitative procedures for the separation of the protein components of human plasma. J. Amer. chem. Soc. 1950, 72, 465.

20. Helmkamp, R. W., R. L. Goodland, W. F. Bale, I. L. Spar, and L. E. Mutschler. High specific activity iodination of $\gamma$-globulin with iodine-131 monochloride. Cancer Res. 1960, 20, 1495.

21. Kunkel, H. G., and R. J. Slater. Zone electrophoresis in a starch supporting medium. Proc. Soc. exp. Biol. (N. Y.) 1952, 80, 42.

22. Kunkel, H. G. Macroglobulins and high molecular weight antibodies in The Plasma Proteins, F. W. Putnam, Ed. New York, Academic Press, 1960, vol. 1, p. 294.

23. Neff, J. C., and E. L. Becker. Antigen-antibody reactions in agar. III. Rate of change of band migration with antigen concentration. J. Immunol. 1957, 78, 5 .

24. Grey, H. M., and H. G. Kunkel. H chain subgroups of myeloma proteins and normal 7S $\gamma$-globulin. J. exp. Med. 1964, 120, 253.

25. Terry, W. D., and J. L. Fahey. Subclasses of human $\gamma_{2}$-globulin based on differences in the heavy polypeptide chains. Science 1964, 146, 400.

26. Mannik, M., and H. G. Kunkel. Two major types of normal 7S $\gamma$-globulin. J. exp. Med. 1963, 117, 213.

27. Korngold, L., and G. Van Leeuwen. The effect of the antigen's molecular weight on the curvature of the precipitin line in the Ouchterlony technic. J. Immunol. 1957, 78, 172.

28. Hanson, L. A., and E. M. Tan. Characterization of antibodies in human urine. J. clin. Invest. 1965, 44, 703 .

29. Seijffers, M. J., H. L. Segal, and L. L. Miller. Separation of pepsinogen II and pepsinogen III from human urine. Amer. J. Physiol. 1964, 206, 1106.
30. Poulik, M. D. $F^{\prime} c$ fragment of immunoglobulins. Nature (Lond.) 1966, 210, 133.

31. Chen, P. S., Jr. Liquid scintillation counting of $\mathrm{C}^{14}$ and $\mathrm{H}^{3}$ in plasma and serum. Proc. Soc. exp. Biol. (N. Y.) 1958, 98, 546.

32. Turner, M. W., and D. S. Rowe. A naturally occurring fragment related to the heavy chains of immunoglobulin $G$ in normal human urine. Nature (Lond.) 1966, 210, 130.

33. Gitlin, D., J. Kumate, J. Urrusti, and C. Morales. The selectivity of the human placenta in the transfer of plasma proteins from mother to fetus. J. clin. Invest. 1964, 43, 1938.

34. Spiegelberg, H. L., and W. O. Weigle. The catabolism of homologous and heterologous $7 \mathrm{~S}$ gamma globulin fragments. J. exp. Med. 1965, 121, 323.

35. Franklin, E. C. Structural studies of human 7S $\gamma$-globulin (G immunoglobulin). Further observations of a naturally occurring protein related to the crystallizable (fast) fragment. J. exp. Med. 1964, 120, 691.

36. Cohen, S., and R. R. Porter. Structure and biological activity of immunoglobulins. Advanc. Immunol. 1964, 4, 287.

37. Martin, R. G., and B. N. Ames. A method for determining the sedimentation behavior of enzymes: application to protein mixtures. J. biol. Chem. 1961, 236, 1372.

38. Remington, J. S., and M. Finland. Precipitating antibody in normal human urine. Proc. Soc. exp. Biol. (N. Y.) 1961, 107, 765.

39. Remington, J. S., E. Merler, A. M. Lerner, D. Gitlin, and $M$. Finland. Antibodies of low molecular weight in normal human urine. Nature (Lond.) 1962, 194, 407.

40. Solomon, A., T. A. Waldmann, J. L. Fahey, and A. S. McFarlane. Metabolism of Bence Jones proteins. J. clin. Invest. 1964, 43, 103. 